Jurnal Intelektualita: Keislaman, Sosial, dan Sains

Vol. 9 No. 2 (2020)

DOI: https://doi.org/10.19109/intelektualita.v9i2.6755

Copyright (C) 2020 Rosidah, Akil, Taufik Mustofa

\title{
Pengaruh Penerapan Model Pembelajaran Number Head Together (NHT) terhadap Hasil Belajar Siswa pada Mata Pelajaran Aqidah Akhlak MI Al-Wasthiyah Kotabaru Karawang
}

\author{
Rosidah $^{1 *}$, Akil $^{1}$, Taufik Mustofa ${ }^{1}$ \\ ${ }^{1}$ Universitas Singaperbangsa Karawang, Indonesia
}

\begin{abstract}
Abstrak: Penelitian ini bertujuan untuk mengetahui pengaruh penerapan model Numbered Heads Together terhadap hasil belajar siswa kelas III pada mata pelajaran aqidah akhlak kelas III di MI AlWasthiyah Kotabaru Karawang. Penelitian ini menggunakan pendekatan kuantitatif dan metode penelitian Quasi Eksperimental Design dengan populasi seluruh siswa kelas III MI AL-Wasthiyah Kotabaru Karawang pada tahun ajaran 2019/2020. Desain dalam penelitian ini adalah Noneequivalen Control Group Design dengan teknik purposive sampling pengambilan sampel dari populasi dilakukan tidak secara acak. Berdasarkan analisis uji perbedaan rata-rata pada tahap akhir diperoleh bahwa nilai $\mathrm{T}_{\text {hitung }}$ sebesar $2,913>\mathrm{T}_{\text {tabel }} 2,048$ dengan sig. $(0,010)<\mathrm{a}(0,05)$ menunjukkan terdapat pengaruh yang tinggi sehingga dapat dikatakan adanya pengaruh penerapan model pembelajaran Numbered Head Together terhadap hasil belajar siswa kelas III pada mata pelajaran Aqidah akhlak di MI Al-Wasthiyah Kotabaru Karawang.
\end{abstract}

Kata Kunci: hasil belajar, model pembelajaran numbered head together (nht)

\begin{abstract}
This study aims to determine the effect of the application of the Numbered Heads Together model on the learning outcomes of class III students in class III aqidah morals at MI AlWasthiyah Kotabaru Karawang. This study uses a quantitative approach and a Quasi Experimental Design research method with a population of all class III students of MI AL-Wasthiyah Kotabaru Karawang in the 2019/2020 school year. The design in this study is Noneequivalent Control Group Design with purposive sampling technique sampling from the population is done not randomly. Based on the analysis of the average difference test at the final stage, it was found that the value of $t$ count was 2.913> t table 2.048 with sig. $(0.010)<a(0.05)$ indicates that there is a high influence so that it can be said that there is an effect of the application of the Numbered Head Together learning model on the learning outcomes of class III students in the subject of Aqidah morals at MI AlWasthiyah Kotabaru Karawang.
\end{abstract}

Keywords: learning outcomes, numbered head together (nht) learning model

\section{Pendahuluan}

Manusia dapat merubah dirinya sesuai dengan apa yang didapat dalam pengalaman belajarnya. Belajar adalah kegiatan pokok dalam suatu proses pendidikan dimana pendidik dan peserta didik berada dalam suatu ruang lingkup dan melakukan interaksi belajar mengajar untuk mencapai tujuan dalam pendidikan. Belajar merupakan suatu proses perubahan yaitu perubahan tingkah laku sebagai hasil dari interaksi dengan lingkungannya dalam memenuhi kebutuhan

\footnotetext{
* Corresponding Author: Rosida (rosidahrosi04@gmail.com). Universitas Singaperbangsa Karawang, Indonesia
} 
hidupnya (Slameto, 2018). Dalam proses belajar tentunya sangat berkaitan erat dengan Pendidik dan peserta didik. Dimana pendidik merupakan fasilitator untuk peserta didik belajar. Peserta didik juga menjadi penentu terjadi atau tidaknya proses belajar. Belajar adalah suatu proses untuk mengetahui suatu yang belum diketahui yang akan membuka wawasan, menambah pengetahuan dan akan merubah sikap atau perilaku menjadi lebih baik . Proses belajar tidak akan pernah lepas dari hasil belajar. Hasil belajar adalah suatu tolak ukur untuk mengetahui sejauh mana atau sebisa mana peserta didik dapat memahami ilmu yang sudah diajarkan oleh pendidik dalam kegiatan belajar mengajar disuatu lembaga. Hasil belajar sangat berkaitan erat dengan proses belajar mengajar, dimana belajar merupakan proses untuk mendapatkan hasil belajar.

Berhasil atau tidaknya suatu proses pembelajaran tergantung dari pendidik yang memberikan pengarahan dalam proses pembelajaran agar dapat berlangsung proses pembelajaran yang ideal dan agar mendapatkan hasil belajar yang baik. Oleh karena itu peran guru dalam hal ini sangat penting. Guru perlu menciptakan suasana kelas yang kondusif yaitu suasana belajar yang menyenangkan, aman, menarik dan dapat memberikan ruang kepada siswa untuk berpikir aktif, kreatif dan inovatif dalam mengeksplorasi kemampuannya untuk mencapai tujuan pembelajaran yang diharapkan.. Selain itu kegiatan belajar peserta didik dipengaruhi oleh berbagai faktor seperti motivasi, kematangan, hubungan peserta didik dengan guru, kemampuan verbal tingkat kebebasan, rasa aman, dan keterampilan guru dalam berkomunikasi (Mulyasa, 2016). Dalam proses pembelajaran biasanya guru hanya menggunakan model pembelajaran konvensional yang membuat peserta didik merasa bosan dan jenuh. Bahkan tidak sedikit guru mengajar dengan model pembelajaran yang tidak sesuai dengan materi yang diajarkan sehingga membuat siswa pasif enggan bertanggung jawab dengan tugas yang dapat mempengaruhi terhadap hasil belajarnya yang tidak sesuai dengan standar yang telah ditentukan oleh pihak sekolah..

Dalam kasus ini variasi model pembelajaran sangat dibutuhkan untuk menarik perhatian dan minat siswa. Guru perlu menguasai beberapa model pembelajaran agar dalam proses belajar mengajar berlangsung efektif dan tidak membosankan untuk peserta didik. Hal ini juga dapat berpengaruh pada hasil belajar siswa. jika guru menggunakan model pembelajaran yang sesuai dengan materi yang dipelajari maka akan baik pula hasil belajar yang didapatkan peserta didik. Model atau desain pembelajaran merupakan prosedur kerja yang digunakan dalam proses pembelajaran agar pembelajaran dapat dilaksanakan secara baik dan menghasilkan output yang baik. Prosedur kerja tersebut memiliki tahapan-tahapan, antara lain adalah analisis, perencanaan, pengembangan, implementasi dan evaluasi (Mudlofir, 2017).

Ada beberapa model pembelajaran yang baik dalam mengatasi permasalahan itu, penulis mengambil model pembelajaran Numbered Head Together (NHT) karena menurut penulis model pembelajaran itu sangat menarik dan akan sangat berpengaruh pada hasil belajar siswa. Peserta didik merupakan pihak yang terlibat langsung dan merasakan langsung dampak proses belajar mengajar. Oleh karena itu pemilihan metode yang tepat dalam proses pembelajaran adalah suatu keharusan seorang pendidik agar hasil belajar siswa dapat meningkat dan siswa mampu memahami apa yang telah dipelajarinya sehingga siswa dapat menerapkannya dalam kehidupan sehari-hari dan apa yang menjadi tujuan Pendidikan Agama Islam dapat tercapai. Maka dari itu Aqidah Akhlak sangatlah penting untuk dipelajari. Dengan 
menggunakan model dalam proses pembelajaran diharapkan dapat meningkatkan pemahaman, mempunyai pengalaman, dapat menjadi manusia yang bermanfaat untuk orang lain, mempunyai akhlak yang mulia yang diharapkan dapat meningkatkan hasil belajar terutama di MI AlWasthiyah Kotabaru Karawang.

Ironisnya, model pembelajaran cooperative learning belum banyak diterapkan dalam Pendidikan. Kebanyakan pengajar enggan menerapkan model pembelajaran ini dalam proses pembelajaran berlangsung karena ada beberapa alasan. Kekacauan di kelas dan siswa tidak belajar jika mereka di tempatkan dalam grup, selain itu banyak siswa yang tidak bekerja sama dengan baik hanya mengandalkan teman teman dalam kelompoknya. Sebenarnya pembagian kerja yang kurang adil tidak perlu terjadi dalam kerja kelompok jika pengajaran benar-benar menerapkan prosedur model pembelajaran cooperative Learning tipe Numbered Heads Together.

Pendidik sangat berpengaruh dalam keberhasilan peserta didik sebab bukan hanya mampu menguasai materi namun juga membangun konsep agar dapat menjadikan proses pembelajaran berjalan dengan baik dan mendapatkan hasil yang baik untuk peserta didik.

\section{Metode Penelitian}

Penelitian ini berbentuk penelitian kuantitatif, yang terdapat dua macam variabel yaitu variabel bebas pembelajaran Numbered Head Together (NHT) dan variabel terikat Hasil Belajar Siswa. Dalam mengumpulkan data peneliti menggunakan dua cara yaitu dengan kuisioner (angket) dan dokumentasi. Ada dua sumber dalam penelitian ini sumber utama (primer) dan sumber pendukung (sekunder). Yang menjadi sumber utama penelitian ini yaitu kuisioner (angket) yang di isi oleh responden dan yang menjadi sumber pendukung berupa foto maupun dokumen tertulis. Peneliti dalam menganalisis data menggunakan beberapa teknik analisis data, analisis data dengan uji validitas, kemudian uji realibilitas, uji normalitas, uji homogenitas, uji $\mathrm{R}$, uji $\mathrm{T}$, dan uji determinasi. Sebelum melakukan pengelohan data peneliti terlebih dahulu mempersiapkan kisi-kisi instrument penelitian.

\section{Hasil Penelitian dan Pembahasan}

Pada bagian ini akan disampaikan beberapa hasil penelitian yang diperoleh oleh peneliti selama 2 pertemuan dengan masing-masing melakukan pretest dan posttest. Penelitian ini bertujuan untuk menganalisa pencapaian dan peningkatan kemampuan hasil belajar yang mendapatkan model pembelajaran Cooperative learning tipe Numbered Head Together lebih baik dari pada yang mendapatkan model pembelajaran konvensional. Peneliti mengambil kelas III MI Al-Wasthiyah sebanyak dua kelas untuk dijadikan kelas kontrol dan eksperimen. Penelitian ini menggunakan purposive sampling. Dengan mengambil sampel sebanyak dua kelas yaitu kelas III A dan kelas III B, dimana untuk kelas III B sebagai kelas eksperimen dengan menggunakan model pembelajaran Numbered Head Together (NHT) dan kelas III A sebagai kelas kontrol dengan menggunakan pembelajaran konvensional. Kedua kelas diberi materi pelajaran yang sama yaitu Akhlakul karimah terhadap saudara dalam kehidupan sehari-hari.

Berdasarkan analisis hasil penelitian pada data pretest kelas kontrol diperoleh rata-rata 58,3 dan kelas eksperimen 57. Hasil rata-rata pretest menunjukkan bahwa beda kelas memiliki kemampuan awal yang tidak jauh berbeda dengan perbedaan nilai hanya 1,3. Rata-rata pretest eksperimen lebih rendah dibandingkan nilai pretest kelas kontrol, namun nilai tersebut masih sangat 
jauh dari nilai ideal yaitu 100 atau peserta didik mendapatkan minimal nilai harus melebihi KKM.

Sebelum penggunaan instrumen ini, terlebih dahulu soal diuji dengan analisis uji soal. Soal yang memenuhi kriteria tersebut dapat dijadikan instrumen dalam penelitian. Instrumen yang digunakan sebagai alat ukur hasil belajar 10 butir soal yang memenuhi kriteria valid dan reliabel yang bisa digunakan untuk penelitian. Hasil belajar Aqidah akhlak pada kelompok eksperimen diperoleh rata-rata 85 dan kelompok kontrol diperoleh rata-rata 75,3 . Sehingga menunjukkan bahwa ada pengaruh model pembelajaran kooperatif tipe Numbered Heads Together terhadap hasil belajar akidah akhlak. Hal ini sesuai dengan perhitungan uji beda rata-rata/ Paired Sample TTest memaparkan nilai $\mathrm{T}_{\text {hitung }}$ sebesar 2,913 $>\mathrm{T}_{\text {tabel }}$ 2,048 dengan sig. $(0,010)<a(0,05)$, menunjukkan terdapat beda rata-rata antara pretest dengan posttest secara signifikan.

Dari data N-Gain kelas kontrol rata-rata mendapat 0,41 dan dari data $\mathrm{N}$-Gain kelas eksperimen rata-rata mendapat 0,65 Sehingga dapat disimpulkan bahwa ada pengaruh model pembelajaran kooperatif tipe Numbered Heads Together terhadap hasil belajar pada mata pelajaran aqidah akhlak kelas III MI Al-Wasthiyah sebesar $24 \%$ dan sisanya disebabkan oleh faktor lain seperti faktor intern misalnya seperti faktor kesehatan atau minat atau faktor ekstern misalnya faktor dari keluarga atau lingkungan yang dapat mempengaruhi proses belajar.

\section{Kesimpulan}

Penerapan metode Numbered Head Together (NHT) pada mata pelajaran aqidah akhlak di MI AlWasthiyah dilakukan sesuai prosedur penelitian eksperimen yang terdiri dari 4 tahap yaitu perencanaan, pemberian pre-test, tindakan dan pemberian post-test. Dari data N-Gain kelas kontrol rata-rata mendapat 0,41 dan dari data $\mathrm{N}$-Gain kelas eksperimen rata-rata mendapat 0,65 Sehingga dapat disimpulkan bahwa ada peningkatan hasil belajar menggunakan model pembelajaran kooperatif tipe Numbered Heads Together terhadap hasil belajar pada mata pelajaran aqidah akhlak kelas III MI AlWasthiyah sebesar 24\% hal ini dapat dilihat dari nilai post test kelas eksperimen rata-rata nilai yang diperoleh adalah 85 sedangkan kelas kontrol ratarata nilai yang diperoleh adalah 75,3. Berdasarkan analisis uji perbedaan rata-rata pada tahap akhir diperoleh bahwa nilai $\mathrm{T}_{\text {hitung }}$ sebesar 2,913 $>\mathrm{T}_{\text {tabel }}$ 2,048 dengan sig. $(0,010)<a(0,05)$, menunjukkan terdapat pengaruh yang tinggi sehingga dapat dikatakan adanya pengaruh penerapan model pembelajaran Numbered Head Together terhadap hasil belajar siswa kelas III pada mata pelajaran Aqidah akhlak di MI Al-Wasthiyah Kotabaru Karawang.

\section{Daftar Pustaka}

Mudlofir, Ali dan Evi Fatimatur Rusydiyah. 2017. Desain Pembelajaran Inovatif dari Teori dan Praktik. Jakarta: Rajawali Pers

Padjrin, P. (2016). Pola Asuh Anak dalam Perspektif Pendidikan Islam. Jurnal Intelektualita: KeIslaman, Sosial Dan Sains, 5(1), $\quad 1 \quad-14$. https://doi.org/https://doi.org/10.19109/intele ktualita.v5i1.720

Zaini, H., Hadi, A., Sofyan, F. A., \& Hamzah, A. (2021). Covid-19 and Islamic Education in School: Searching for Alternative Learning Media. Webology, 18(1).

Mulyasa, E. 2016. Menjadi Guru Profesional. Bandung: PT REMAJA ROSDAKARYA.

Slameto. 2018. Belajar dan Faktor-faktor yang Mempengaruhinya. Jakarta : PT RINEKA CIPTA. 